\title{
Optimasi Sistem Pembangkit Listrik Tenaga Angin Dan Pembangkit Listrik Tenaga Diesel Berbasis Fuzzy Logic
}

\author{
Mochammad Apriyadi Hadi Sirad \\ Dapartement of Electrical Engineering, \\ Faculty of Engineering, Khairun University \\ apriyadisirat@unkhair.ac.id
}

\begin{abstract}
Abstrak - Penelitian ini bertujuan untuk mengetahui potensi energi angin, kapasitas daya yang mampu tenaga angin, simulasi logika Fuzzy sistem hibrida dalam melayani beban, dan mengetahui sistem operasi ekonomis Hybrid Wind Power dan Solar Power. Untuk mengetahui kapasitas daya mampu kemudian melakukan tes dengan memberikan beban mulai dari beban rendah, menengah, dan tinggi pada angin pembangkit listrik simulasi fuzzy logic. digunakan untuk sistem Hybrid menggabungkan tenaga angin dan Genset dalam sistem bekerja sama dalam pelayanan beban. Sedangkan hasil perhitungan harga ekonomis kWh yang diperoleh pada sistem hibrida tenaga angin dan tenaga diesel Rp 2.076/kWh lebih mahal daripada harga tenaga angin $\mathrm{Rp} 773 / \mathrm{kWh}$ tapi lebih murah dibanding rupiah. Genset 2240/kWh. Dengan kombinasi sistem hibrida tanaga angin dan diesel maka dapat mengurangi biaya operasi, yaitu bahan bakar selain mampu memberikan pasokan tenaga listrik yang berkesinambungan.
\end{abstract}

Keywords: Tenaga Angin, Solar Power, fuzzy Logic, ekonomis operasi.

\section{PENDAHULUAN}

Energi listrik adalah kebutuhan yang sangat penting dalam kehidupan manusia. Banyak manfaat energi listrik untuk penerangan, antara lain informasi, dan lain-lain. Energi listrik dihasilkan dari berbagai pembangkit listrik, baik dari sumber energi baru terbarukan dan sumber energi terbarukan yang tidak suka pembangkit listrik yang menggunakan bahan bakar seperti pembangkit listrik tenaga diesel (tenaga Diesel)
[1], [5]. Daya diesel adalah pembangkit listrik dengan biaya operasi yang tinggi dengan penggunaan bahan bakar yang merupakan sumber energi tidak terbarukan satu kali akan kehabisan cadangan. Hal ini juga semakin mahal harga bahan bakar [6]. Tenaga diesel juga ramah lingkungan karena tanaman tidak menghasilkan dampak emisi seperti Cox, NOx, SOX, dan lain-lain. Untuk mengurangi penggunaan bahan bakar fosil yang menyebabkan polusi, kemudian memegang sistem tenaga hibrida [9].

Seiring dengan perkembangan, pemanfaatan tanaman hibrida memang mengandalkan potensi energi lokal di Hybrid ini menggabungkan pembangkit listrik tenaga diesel dengan jenis sumber energi terbarukan ini adalah energi angin. Penggunaan energi angin akan menghantam polusi udara dari pembakaran bahan bakar, ada beberapa manfaat dari aplikasi potensi energi dalam hibrida yaitu minyak solar mengurangi penggunaan signifikan mengurangi biaya operasional [7].

Energi angin diharapkan dapat mengurangi atau bahkan jika Anda mampu untuk menggantikan peran tenaga diesel sebagai penyedia utama energi listrik, di mana tenaga angin dikombinasikan dengan tenaga diesel untuk mencegah pemadaman listrik [8]. Sistem pembangkit tenaga hibrida pada tenaga angin dan tenaga diesel terdiri dari sumber energi angin sebagai sumber energi utama dan diesel sebagai cadangan jika ketersediaan angin terbatas untuk beberapa hari atau sampai beberapa minggu. Dari paparan di atas, maka peneliti tertarik untuk meneliti sistem optimalisasi pembangkit listrik tenaga hibrida dan pembangkit listrik berbahan dasar fuzzy Logic. 


\section{TEORI DASAR}

Pembangkit tenaga angin bekerja dengan mengubah energi kinetik dari angin yang dihasilkan menjadi energi listrik. Komponen utama dari tanaman adalah turbin angin energi angin (angin turbin), unit Generator listrik (unit pembangkit listrik) dan controller (Controller) [2]. Hal yang perlu diperhatikan di pembangkit listrik tenaga angin adalah tip Speed Ratio (TSR). Untuk menghitung TSR dapat digunakan dalam rumus:

$$
\operatorname{TSR}(\lambda)=\frac{\text { Speed Rotor Tip }}{\text { Wind Speed }}=\frac{v}{V}=\frac{\omega r}{V}=\frac{2 \pi n r}{V}
$$

Where:

$$
\begin{aligned}
& \mathrm{V}=\text { Wind speed }(\mathrm{m} / \mathrm{s}) \\
& \mathrm{v}=\text { Rotary speed of the rotor }(\mathrm{m} / \mathrm{s}) \\
& \mathrm{r}=\text { The radius of the rotor }(\mathrm{m}) \\
& \mathrm{f}=\text { The frequency of rotation of the }(\mathrm{Hz})\left(\mathrm{Sec}^{-1}\right) \\
& \mathrm{n}=\text { Round shaft paddles every seconds }(\mathrm{rps}) \\
& \\
& \quad \text { the assumption }: \mathrm{f}=\mathrm{n}
\end{aligned}
$$

TSR mempengaruhi kecepatan rotasi roda (RPM). Hubungan TSR dengan kecepatan laju poros kecepatan poros (SS):

$$
\mathrm{SS}=\frac{60 \lambda V}{\pi D} \quad(\mathrm{RPM})
$$

Sementara SWEP rotor area (A) pada turbin angin yang diformulasikan (Patel, M. R, 1999):

$$
\mathrm{A}=\frac{\pi}{4} \mathrm{D}^{2}
$$

Kecepatan angin diformulasikan:

$$
\mathrm{V}=\frac{S S}{60} \cdot \mathrm{A} \quad=\frac{S S}{60} \cdot \frac{\pi}{4} \cdot \mathrm{D}^{2}
$$

Ekonomis dalam operasi ada hal yang perlu diketahui termasuk: biaya investasi awal, perkiraan usia peralatan, biaya operasional dan pemeliharaan, suku bunga, dan kebutuhan bahan bakar [6]. Harga rata-rata listrik dalam satu tahun:

$$
\mathrm{C}_{1}=\left(\frac{P}{n}\right)+\left\{\frac{(P \times i)}{2}\right\}\left\{\frac{(n+1)}{n}\right\}+(\mathrm{O}+\mathrm{M})
$$

Harga listrik (per kWh)

$$
\mathrm{C}=\frac{\text { The price of electrical energy per year }}{\text { The energy generated per year }}
$$

\section{METODOLOGI PENELITIAN.}

Fungsi simulasi ini untuk mengetahui karakteristik antara putaran turbin, tegangan output, dan kecepatan angin. Simulasi ini dilakukan dengan menggunakan variabel input DC yang terkait dengan motor DC, motor DC yang terhubung ke pembangkit listrik tenaga angin digunakan untuk memutar turbin. Dari output pengukuran tegangan pertanian angin dilakukan dengan menggunakan AVO-meter sedangkan untuk pengukuran yang digunakan digital Tachometer.

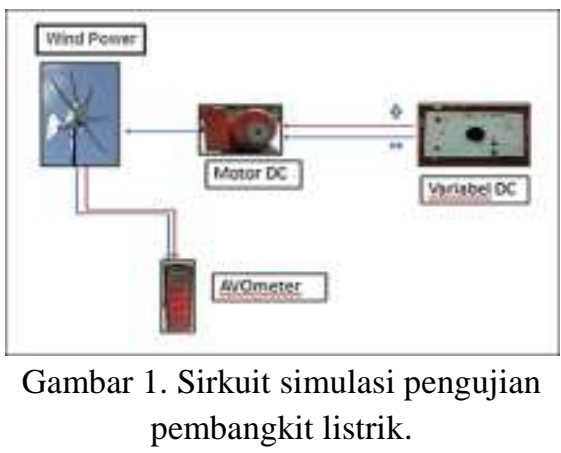

Simulasi ini akan tidak divalidasi, Karakteristik dari perputaran turbin, tegangan, dan kecepatan angin, langkah selanjutnya melakukan analisa potensi angin. Dari analisis data akan diambil potensi energi angin dalam satu tahun dan potensi energi angin rata-rata harian.

Uji besarnya kapasitas daya yang mampu sangat penting karena pada energi terbarukan, output daya tidak stabil. Berbeda dengan sumber energi lain yang berasal dari perusahaan pembangkit listrik negara Indonesia dan output daya Genset lebih stabil.

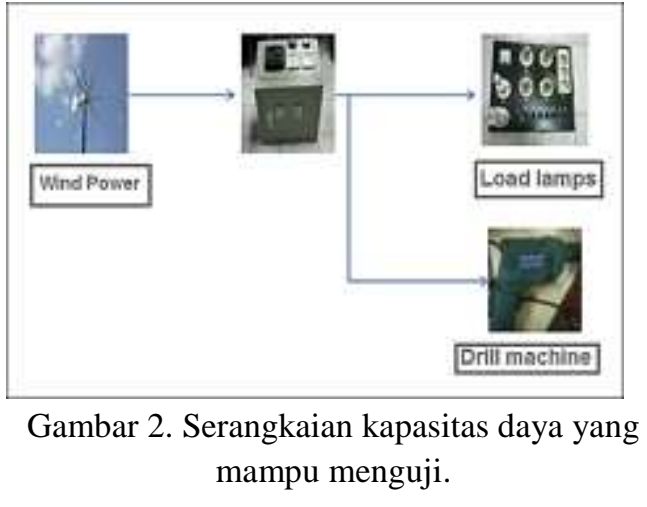

Dalam pengujian kapasitas daya mampu pembangkit listrik tenaga angin dilakukan dengan memberikan beban seperti lampu dengan nilai yang berbeda dan peralatan beban mulai dari beban 
rendah, menengah ke beban tinggi. Metode metode logika Fuzzy yang digunakan adalah min-Max Mamdani. Pada tahap metode Defuzzifikasi Centroid yang digunakan. Adapun simulasi dilakukan dengan bantuan Matlab 7,6 R 2008 di fuzzy Toolbox [4]. Optimalisasi sistem perhitungan pembangkit listrik di pembangkit listrik tenaga hibrida dan tenaga angin mengandung komponen penting dari generator Harap dicatat bahwa adalah perhitungan biaya awal baik dari pembangkit listrik tenaga angin dan tenaga diesel, bahan bakar listrik diesel Biaya konsumsi, kapasitas daya output dari angin pembangkit listrik dan tenaga diesel, dan lain-lain. Hasil perhitungan ekonomis diharapkan dapat memberikan gambaran tentang nilai ekonomi pembangkit listrik tenaga angin dan tenaga Diesel pembangkit tenaga Hybrid.

\section{IV.HASIL DAN PEMBAHASAN}

Dari hasil pengukuran simulasi pembangkit listrik tenaga angin telah dilakukan terlihat dalam tabel di bawah ini:

Tabel 1. Hasil pengukuran, tegangan, dan kecepatan angin

\begin{tabular}{ccc}
\hline $\begin{array}{l}\text { Putaran } \\
\text { (rpm) }\end{array}$ & $\begin{array}{l}\text { Tegangan } \\
\text { (volt) }\end{array}$ & $\begin{array}{l}\text { kecepatan angin } \\
(\mathbf{m} / \mathbf{s})\end{array}$ \\
\hline 115 & 3 & 1.5 \\
125 & 4 & 1.7 \\
154 & 5 & 2 \\
185 & 6 & 2.4 \\
225 & 7 & 2.9 \\
255 & 8 & 3.3 \\
285 & 9 & 3.7 \\
313 & 1 & 4.1 \\
355 & 11 & 4.4 \\
383 & 12 & 5 \\
425 & 13 & 5.5 \\
455 & 14 & 5.9 \\
485 & 15 & 6.3 \\
525 & 16 & 6.8 \\
565 & 17 & 7.2 \\
611 & 18 & 8 \\
\hline
\end{tabular}

Dari tabel 1 di atas diperoleh kecepatan angin yang dapat dimanfaatkan untuk pembangkit listrik yang kecepatan hingga $5 \mathrm{~m} / \mathrm{s}$ pada tegangan 12 volt, itu akan sesuai dengan rentang nilai alat ini pada $5-8 \mathrm{~m} / \mathrm{s}$. semakin besar kecepatan angin, semakin besar kecepatan rotasi turbin dan juga semakin besar tegangan yang dihasilkan pula. Hasil analisis data kecepatan angin, yang dapat dimanfaatkan 2275 jam atau rata-rata 6 jam/hari.
Di pembangkit listrik tenaga angin memiliki output daya 200 watt dengan 1000 watt Inverter. Diukur tegangan, saat ini, kekuasaan, dan perubahan dalam beban dengan menggunakan perangkat lunak Lucas Nulle. Hasil pengukuran adalah sebagai berikut:

Tabel 2. Potensi energi angin

\begin{tabular}{cc}
\hline Bulan & $\begin{array}{c}\text { Potensi angin } \\
\text { (Hours) }\end{array}$ \\
\hline January & 254 \\
February & 204 \\
March & 190 \\
April & 175 \\
May & 142 \\
June & 101 \\
July & 96 \\
August & 192 \\
September & 253 \\
October & 231 \\
November & 217 \\
December & 220 \\
\hline Jumlah (per tahun) & 2276 \\
\hline Rerata harian & 6.2 \\
\hline
\end{tabular}

Tabel 3. Hasil pengukuran kapasitas daya mampu

\begin{tabular}{lccc}
\hline \multicolumn{1}{c}{ Beban (watt) } & $\begin{array}{c}\text { Tegangan } \\
\text { (V) }\end{array}$ & $\begin{array}{c}\text { Arus } \\
(\mathbf{A})\end{array}$ & $\begin{array}{c}\text { Daya } \\
(\mathbf{W})\end{array}$ \\
\hline Without Load & 230 & 0.07 & 16.22 \\
Lamp 5 watt & 221.6 & 0.102 & 22.52 \\
Lamp 10 watt & 217.6 & 0.128 & 27.89 \\
Lamp 8 watt & 226.9 & 0.092 & 20.83 \\
Lamp 25 watt & 220.3 & 0.144 & 31.8 \\
Lamp 40 watt & 216.2 & 0.218 & 47.3 \\
Lamp 18 watt & 221.9 & 0.152 & 33.8 \\
Lamp 106W & 208.9 & 0.644 & 134.5 \\
lamp 200 Watt & 206.6 & 0.908 & 187.6 \\
Electric drill 500 Watt & 213.6 & 1.03 & 219.9 \\
Lamp + drill (606) & 210.5 & 1.24 & 260.4 \\
Lamp + drill (806) & 206.5 & 1.42 & 293.23 \\
\hline
\end{tabular}

Hasil pengukuran Inverter output dalam tabel 5 yang diperoleh pada beban rendah tidak ada perubahan yang signifikan terhadap tegangan, tetapi beban tegangan menurun, arus, dan kekuasaan. Semakin besar 
beban yang diberikan aliran semakin besar. Sementara turbin bulat yang lebih besar kemudian stabil pengisian.

Tabel 4. Hasil dari tahapan kesimpulan

\begin{tabular}{cccc}
\hline No. & $\begin{array}{c}\text { Tenaga } \\
\text { angin }\end{array}$ & Ganset & Beban \\
\hline 1 & Low & Minimum & Very Low \\
2 & Low & Very Low & Very Low \\
3 & Low & Low & Low \\
4 & Low & Medium & Low \\
5 & Low & High & Medium \\
6 & Low & Very High & Medium \\
7 & Medium & Maximum & High \\
8 & Medium & Minimum & Very Low \\
9 & Medium & Very Low & Low \\
10 & Medium & Low & Low \\
11 & Medium & Medium & Medium \\
12 & Medium & High & Medium \\
13 & Medium & Very High & High \\
14 & High & Maximum & High \\
15 & High & Minimum & Low \\
16 & High & Very Low & Low \\
17 & High & Low & Medium \\
18 & High & Medium & Medium \\
19 & High & High & High \\
20 & High & Very High & High \\
21 & High & Maximum & Very High \\
\hline & & &
\end{tabular}

Tabel 5. Hasil tahapan defuzzifikasi

\begin{tabular}{ccc}
\hline Fuzzifikasi & Defuzzifikasi \\
\hline $\begin{array}{c}\text { Pembangkit listrik } \\
\text { tenaga angin }\end{array}$ & $\begin{array}{c}\text { Daya } \\
\text { diesel }\end{array}$ & Beban \\
\hline 100 & 400 & 500 \\
200 & 300 & 500 \\
250 & 250 & 500 \\
500 & 500 & 1000 \\
500 & 1000 & 1500 \\
500 & 1500 & 2000 \\
750 & 750 & 1500 \\
750 & 1250 & 2000 \\
750 & 1750 & 2500 \\
\hline
\end{tabular}

Dari hasil penghitungan program operasi dan sistem ekonomi yang menghasilkan tenaga angin dan harga Genset yang didapatkan per kWh untuk pembangkit listrik tenaga angin sebesar Rp 773,7 lebih kecil dari harga Genset Rp. 2.240/kWh. Sementara sistem hibrida pembangkit listrik dan pembangkit listrik tenaga angin menghasilkan harga per kWh sebesar Rp. 2,076, dengan sistem hibrida yang mampu mengurangi konsumsi bahan bakar dan biaya operasional dapat memberikan sumber energi listrik yang berkesinambungan.

\section{KESIMPULAN}

Kesimpulan yang dapat diambil dari hasil penelitian ini adalah simulasi Karakteristik dari peralatan pembangkit listrik tenaga angin yang diperoleh kecepatan angin yang dapat dimanfaatkan untuk sumber energi angin IE $5-8 \mathrm{~m} / \mathrm{s}$. hasil analisis yang diketahui potensi energi adalah 2275 jam atau rata-rata 6 jam/hari. Pengujian kapasitas daya yang mampu memberikan pengenaan beban mulai dari kecil, menengah, dan daya tinggi dalam mendapatkan mampu pembangkit listrik tenaga angin dengan Inverter 1000 watt mampu melayani beban hingga 800 watt. Faktor kecepatan angin sangat mempengaruhi rotasi turbin dan output tegangan dari pembangkit listrik tenaga angin sehingga efek pada stabilitas pengisian baterai. Hasil simulasi logika Fuzzy menunjukkan sistem kombinasi Divisi beban yang sangat baik. Dimana Diperoleh konfigurasi sistem dimana kedua tanaman mampu bekerja sama dalam melayani beban. Dari hasil perhitungan dan program dalam harga Get per kWh untuk pembangkit listrik tenaga angin sebesar Rp 773,7 jauh lebih kecil daripada harga Genset yaitu Rp. 2.240/kWh. Sedangkan harga per kWh sebesar rupiah. sistem hibrida 2,076, karena kombinasi dari sistem hibrida generasi kedua yang dapat mengurangi konsumsi bahan bakar dan biaya operasi dapat menyediakan sumber energi listrik berkelanjutan.

\section{DAFTAR PUSTAKA}

[1]. Daryanto,K." Studi tentang potensi angin untuk pembangkit listrik tenaga angin ”,Yogyakarta, 2010

[2]. H. Gitano, S. Taib, M. Khdeir. Desain dan pengujian Low Cost Peak-Power Tracking controller untuk Blade tetap 1,2 kVA turbin angin. kualitas daya listrik dan jurnal pemanfaatan, Vol. XIV, No. 1, pp. 95-101. 2014

[3]. Marsudi, Djiteng. "Pengoperasian sistem tenaga listrik”. Jakarta. Penerbit Graha Ilmu, 2010

[4]. Muhamad Jamshidi, Nader Vadiee “ Fuzzy Logic and Control " Prentice - hall International, Inc.

[5]. Patel Mukund R."Wind and Solar Power Sistems"CRC Press Boca Raton, London New York, Washington DC. 2013. 
[6]. Rifaldi $\mathrm{M}^{1)}$, Era $\mathrm{P}^{2)}$, Arman J ${ }^{3)}$, Gigih $\mathrm{P}^{4)}$, 'Wind power plant System Uses vertical axis Windmill for Load-home', Seminar on Inteligent Technology and ITS Application', Politeknik Elektronika Surabaya, ITS, Surabaya. 2017.

[7]. Supriono, "Pertimbangan ekonomis untuk pembangkit listrik di daerah terpencil ". Universitas Mataram. 2007

[8]. T.Sutojo, Mulyanto Edy, Suhartono Vincent.“ Artificial Intelligence”. Semarang. Andi Yogyakarta. 2010

[9]. Z. Xu, P. Ge and D. Xu, "High performance control of a permanent magnet wind power generation system using an adaptive sliding observer," in International Conference on Power Electronics and Drive Systems, 2009. 